\title{
A Rapid and Convenient Procedure for the Detection of Inhibitors of DNA Synthesis Using Starfish Oocytes and Sea Urchin Embryos
}

\author{
Susumu IKEGAMI, ${ }^{*}$ Kazushige Kawada, ${ }^{* *}$ Yasuo Kimura and Akinori SUzUKI \\ Department of Agricultural Chemistry, University of Tokyo, Bunkyo-ku, Tokyo 113 \\ Received September 11, 1978
}

\begin{abstract}
A rapid and convenient procedure for the detection of inhibitors of DNA synthesis using starfish oocytes and sea urchin embryos at the 1-cell stage is described. The procedure is based on the findings that inhibitors of DNA synthesis block mitotic cell division of sea urchin embryos which requires DNA synthesis but do not affect meiotic maturational divisions of starfish oocytes which are independent of DNA synthesis. The efficacy of the method is verified by the isolation of aphidicolin, an inhibitor of DNA synthesis, from the culture filtrate of the fungus Harziella entomophila according to the bioassay procedure proposed in this study.
\end{abstract}

Knowledge of the mechanism governing DNA synthesis is central to our understanding of cell proliferation. The study of the control of DNA synthesis would be helped if we had a variety of chemicals which influenced DNA synthesis in various manners. Furthermore, inhibitors of DNA synthesis are of potential clinical use for cancer chemotherapy since many of the antitumor substances have been shown to inhibit DNA synthesis.

In this paper, we descibe a rapid and convenient procedure for the detection of inhibitors of DNA synthesis using starfish oocytes and sea urchin embryos. The procedure is based on the findings that inhibitors of DNA synthesis block cell division of sea urchin embryos at the 1-cell stage which requires DNA synthesis ${ }^{1}$ ) but do not affect meiotic maturational divisions of starfish oocytes which are independent of DNA synthesis. ${ }^{2)}$ The efficacy of the method is verified by the isolation of aphidicolin, an inhibitor of DNA synthesis, from the culture filtrate of the fungus Harziella entomophila according to the bioassay procedure described here.

\section{MATERIALS AND METHODS}

The starfish mainly used in the present study was

* To whom correspondence should be addressed.

** Present address: Central Research Laboratories, Fujisawa Pharmaceutical Co., Higashiyodogawa-ku, Osaka 533.
Asterina pectinifera. The sea urchin mainly used was Clypeaster japonicus. The sea urchins Hemicentrotus pulcherrimus and Anthocidaris crassispina, and the starfish Asterias amurensis were also used in some experiments. They were collected from the coastal waters of Kanagawa during their breeding seasons and kept in laboratory aquaria supplied with running sea water. Culture of oocytes and embryos was carried out at $18^{\circ} \sim 20^{\circ} \mathrm{C}$.

Chemicals. The sea waters used in the present study were natural sea water (NSW) and calcium-free sea water (CaFSW), the latter being composed of $2.3 \%$ $\mathrm{NaCl}, 0.07 \% \mathrm{KCl}, 0.34 \% \mathrm{MgCl}_{2}$ and $0.21 \% \mathrm{MgSO}_{4}$, and adjusted to $\mathrm{pH} 8.0 \sim 8.3$ with $\mathrm{NaHCO}_{3}$ (approximately $0.02 \%$ ). 1- $\beta$-D-Arabinofuranosylcytosine was purchased from Yamasa, Chiba. 5-Fluorouracil was from Nakarai, Kyoto. N-Hydroxyurea, vinblastine sulfate and 1-methyladenine were from Sigma, St. Louis. Actinomycin D, cycloheximide and amphotericine B were gifts from Dr. N. Otake, Institute of Applied Microbiology, University of Tokyo, Tokyo. Aphidicolin was from Dr. B. Hesp, Imperial Chemical Industries, Macclesfield, U. K. Actinomycin D, amphotericine $\mathrm{B}$ and aphidicolin being insoluble in aqueous media were dissolved in dimethylsulfoxide and then dispersed in NSW so as not to exceed the concentration of dimethylsulfoxide $0.1 \%$ in the solution. Dimethylsulfoxide at this concentration did not affect biological assays described below. Other chemicals were dissolved in NSW.

Yeast extract was purchased from Difco Laboratories, Detroit.

The biological assay with starfish oocytes. Starfish oocytes were torn from a ripe ovary with forceps, immediately transferred to CaFSW to remove follicle 
cells and sedimented with a hand centrifuge. They were washed four times by resuspension in CaFSW and allowed to settle for at least $1 \mathrm{hr}$. The oocytes were sedimented and suspended in NSW. The oocytes freed of the follicular envelope were at the germinal vesicle stage of meiosis. The addition of 1-methyladenine $(45 \mathrm{ng} / \mathrm{ml})$ to these oocytes induced synchronous meiotic maturation. ${ }^{3,4}$ The first polar body was expelled $1 \mathrm{hr}$ after the initiation of the treatment and the second one $70 \mathrm{~min}$ later at $18^{\circ} \mathrm{C}$. Morphological changes of the oocytes placed in $0.4 \mathrm{ml}$ of a test solution containing 1 -methyladenine $(45 \mathrm{ng} / \mathrm{ml})$ and a sample of an appropriate concentration were observed at $150 \mathrm{~min}$ after the initiation of the treatment.

The biological assay with sea urchin embryos. Dry sperm of sea urchins obtained by intracoelomic injection of $0.5 \mathrm{M} \mathrm{KCl}$ was stored in the cold until use. Eggs were spawned into NSW by intracoelomic injection of $0.5 \mathrm{M} \mathrm{KCl}$, sedimented with a hand centrifuge and washed three times by resuspension in NSW and allowed to settle until use. The egg divided around 90 min after insemination and the second division occurred $30 \mathrm{~min}$ later at $18^{\circ} \mathrm{C}$. Five min after insemination when fertilization membranes were elevated, the eggs were treated with $0.4 \mathrm{ml}$ of sample solutions. They were examined for morphological changes at 120 min later.

Culture of Harziella entomophila and isolation of aphidicolin. The fungus Harziella entomophila was cultured in the Czapek-Dox medium supplimented with $2 \%$ yeast extract at $26^{\circ} \mathrm{C}$ for 30 days. Then the filtrate (2 liters) was removed from the mycelia by filtration through a paper filter. Aliquots of the filtrate were diluted 10- to 40-fold with NSW and the biological activities were examined. The culture filtrate ( $\mathrm{pH} 8.0)$ was extracted with 1.8 liters of ethyl acetate three times. Extracts were combined and washed with $900 \mathrm{ml}$ of acidified water $(\mathrm{pH} 4.0$ by $\mathrm{HCl}$ ) three times followed by washing with $900 \mathrm{ml}$ of distilled water. Extracts were dried over anhydrous $\mathrm{Na}_{2} \mathrm{SO}_{4}$ and concentrated in vacuo to afford a powder $(42 \mathrm{mg}$ ). Two $\mathrm{mg}$ of the powder was dissolved in $20 \mu \mathrm{l}$ of dimethylsulfoxide and dispersed in $20 \mathrm{ml}$ of NSW. The solution was serially diluted with NSW and the biological activities were assayed as described above. The powder $(40 \mathrm{mg})$ was applied to a Kieselgel $\mathrm{HF}_{254}$ plate $(20 \times 20 \mathrm{~cm})$. After developing with benzene-ethyl acetate-methanol (50: $50: 1, v / v)$, the sulfuric acid-reactive zones were scraped off and extracted with benzene-ethyl acetate-methanol (50:50:1, v/v). Evaporation of the solvents gave powders. Bioassays of an aliquot of each extract were carried out by dissolving it in dimethylsulfoxide and then dispersed in NSW. The biologically active fraction (PC fraction; $5 \mathrm{mg}$ ) was recrystallized from benzenemethanol to afford needles $(2 \mathrm{mg})$. The crystal
$(500 \mu \mathrm{g})$ was bioassayed as described above.

Other methods. Melting points were recorded on a hot plate and were not corrected.

Gas-liquid chromatography was carried out with a Hitachi $\mathrm{K}-53$ gas-chromatograph using a column $(0.3 \times 200 \mathrm{~cm})$ of $3 \%$ Silicone $\mathrm{OV}-1$ on Chromosorb W at $210^{\circ} \mathrm{C}$. The flow rate of the carrier gas, nitrogen, was maintained at $35 \mathrm{ml} / \mathrm{min}$. Samples were converted to acetonides as described by Dalziel et al. ${ }^{\mathrm{b}}$. The acetonides dissolved in acetone were injected into the column.

\section{RESULTS}

Effects of inhibitors of macromolecule syntheses and other chemicals on Echinoderm cell divisions

Effects of $1-\beta$-D-arabinofuranosylcytosine, $\mathrm{N}$-hydroxyurea, 5-fluorouracil, cycloheximide, vinblastine sulfate, actinomycin $\mathrm{D}$ and amphotericine B on the first cleavage of sea urchin (Clypeaster japonicus) embryos and 1-methyladenine-induced meiotic maturational divisions of starfish (Asterina pectinifera) oocytes were examined, and the results are summarized in Table I.

Table I. EfFects of InHibitors of MacroMOLECUle SyNTHESES AND Other Chemicals ON Cell Division of Clypeaster japonicus EMBryos at the 1-Cell Stage and Maturation of Asterina pectinifera OOCYTES INDUCED BY 1-MeTHYLADENINE (45 ng/ml)

\begin{tabular}{lrr}
\hline Chemicals & $\begin{array}{c}\text { Range of minimum effective } \\
\text { concentrations }(\mu \mathrm{g} / \mathrm{ml}) \\
\text { to inhibit cell divisions }\end{array}$ \\
\cline { 2 - 3 } & $\begin{array}{c}\text { Cleavage of } \\
\text { embryos }\end{array}$ & $\begin{array}{c}\text { Oocyte } \\
\text { maturation }\end{array}$ \\
\hline Arabinofuranosylcytosine & $10-1$ & $>100$ \\
N-Hydroxyurea & $>100$ & $>100$ \\
5-Fluorouracil & $>100$ & $>100$ \\
Cycloheximide & $100-10$ & $100-10$ \\
Actinomycin D & $>10$ & $>10$ \\
Vinblastine sulfate & $1-0.1$ & $1-0.1$ \\
Amphotericine B & $1-0.1$ & $1-0.1$ \\
\hline
\end{tabular}

Arabinofuranosylcytosine was shown to be a potent inhibitor of DNA synthesis in eukaryotic cells. ${ }^{6}$ The chemical is converted to the triphosphate derivative in vivo and the phosphate inhibits the activity of DNA polymerase by competing with deoxycytidine tripho- 
sphate. ${ }^{7)}$ Arabinofuranosylcytosine inhibited the first cleavage of the sea urchin embryo but did not affect meiotic maturational divisions in starfish oocytes (Table I). If arabinofuranosylcytosine had any harmful effects on cell functions other than DNA replication which were essential for karyokinesis and cytokinesis to occur, it would affect maturational process of starfish oocytes as well. Such selective inhibition of cell divisions by arabinofuranosylcytosine as revealed in the present study supports the view that the chemical is a selective inhibitor of DNA synthesis in vivo.

$\mathrm{N}$-Hydroxyurea and 5-fluorouracil are known to be inhibitors of deoxyribonucleotide biosynthesis. $^{6)}$ Pools of deoxyribonucleoside triphosphates in sea urchin eggs are high and sufficient to support two or three cycles of DNA replication. ${ }^{8}$ ? Therefore, $\mathrm{N}$-hydroxyurea and 5 -fluorouracil do not affect the first cleavage of sea urchin embryos (Table I). Since maturation of starfish oocytes is unaccompanied by DNA replication, N-hydroxyurea and 5fluorouracil do not affect the divisions. Effects of $\mathrm{N}$-hydroxyurea on early sea urchin embryos and starfish oocytes have been studied by other investigators, ${ }^{2,8}$ and our study confirmed their results.

Cycloheximide is known to inhibit protein synthesis in eukaryotic cells by inhibiting chain initiation as well as chain elongation by acting on the 60-S subunit of the ribosome. ${ }^{9}$ ' Protein synthesis is essential for both cleavage of sea urchin embryos $^{10)}$ and meiotic maturation in starfish oocytes. ${ }^{2)}$ As expected, cycloheximide affected these cell divisions (Table I).

RNA synthesis is quite low during the early cleavage of sea urchin embryos. ${ }^{11}$ ) Maternal messenger RNA synthesized during oogenesis and stored in unfertilized eggs plays a central role in translation. Therefore, actinomycin $\mathrm{D}$, which inhibits RNA-polymerase reaction, ${ }^{12)}$ was shown to be unable to inhibit cleavage of sea urchin embryos by Gross and Cousineau ${ }^{13)}$ The present study confirmed this (Table I). Zampetti-Bosseler et al. ${ }^{2}$ reported that the maturational process in Asterias fobesi oocytes is insensitive to the actinomycin D treatment.
A similar result was obtained here by using Asterina pectinifera oocytes (Table I).

Vinblastine sulfate, an inhibitor of the organization of spindle microtubules in eukaryotic cells, $\left.{ }^{14}\right)$ was effective in inhibiting divisions in both of starfish oocytes and sea embryos (Table I). The microtubule assembly is fundamental for cells to divide either mitotically or meiotically.

Amphotericin B, a polyene antibiotic, has been shown to form an adduct with sterols in plasma membranes resulting in cytolysis in animal cells. ${ }^{15}$ Sea urchin embryos and starfish oocytes sufferred lysis in the presence of the antibiotic. The minimum effective concentrations to block cell divisions in these cells were between $0.1 \sim 1 \mu \mathrm{g} / \mathrm{ml}$ (Table I).

These results show that except for an inhibitor of DNA synthesis, chemicals which affect cell functions to support cell division in sea urchin embryos also affect meiotic maturation in starfish oocytes. Therefore, chemicals which block mitosis in sea urchin embryos without affecting maturation in starfish oocytes may be inhibitors of DNA synthesis.

Isolation of aphidicolin from the culture filtrate of Harziella entomophila as a selectiveinhibitor of mitotic division in sea urchin embryos

In order to exemplify the usefulness of the bioassay system for the detection of inhibitors of DNA synthesis as described in the preceding section, effects of culture filtrates of 50 different actinomycetes and fungi were examined on divisions of sea urchin (Clypeaster japonicus) embryos and starfish (Asterina pectinifera) oocytes. It was found that the culture filtrate obtained from the fungus Harziella entomophila inhibited cleavage of sea urchin embryos but did not affect 1-methyladenine-induced meiotic maturation of starfish oocytes (Table II). Culture filtrates of 11 different strains inhibited both of mitotic division in sea urchin embryos and meiotic maturation in starfish oocytes. Filtrates obtained from the other 38 strains did not block cell divisions of both forms.

The mitosis-inhibitory activity in the filtrate 
of Harziella entomophila was found in the ethyl acetate fraction obtained by extracting the

Table II. Effects of Metabolites of Harziella entomophila at Each Purification Step on Cell

DIVIsION OF Clypeaster japonicus EMBRYOS AT the 1-Cell Stage and Maturation of Asterina pectinifera OOCYTES INDUCED BY 1-MethYLADENINe $(45 \mathrm{ng} / \mathrm{ml})^{\alpha}$

\begin{tabular}{|c|c|c|}
\hline $\begin{array}{l}\text { Purification } \\
\text { steps }\end{array}$ & $\begin{array}{l}\text { Cleavage of } \\
\text { embryos }\end{array}$ & $\begin{array}{c}\text { Oocyte } \\
\text { maturation }\end{array}$ \\
\hline \multicolumn{3}{|l|}{ Culture filtrate } \\
\hline 10-fold diluted & - & + \\
\hline 20 -fold diluted & \pm & + \\
\hline 40-fold diluted & + & + \\
\hline \multicolumn{3}{|c|}{ Ethyl acetate fraction } \\
\hline $100 \mu \mathrm{g} / \mathrm{ml}$ & - & + \\
\hline 50 & - & + \\
\hline 25 & - & + \\
\hline 13 & + & + \\
\hline \multicolumn{3}{|c|}{$\mathrm{PC}$ fraction after recrystallization } \\
\hline $10 \mu \mathrm{g} / \mathrm{ml}$ & - & + \\
\hline 1 & - & + \\
\hline 0.5 & - & + \\
\hline 0.25 & \pm & + \\
\hline 0.13 & + & + \\
\hline \multicolumn{3}{|c|}{ Aphidicolin (authentic) } \\
\hline $10 \mu \mathrm{g} / \mathrm{ml}$ & - & + \\
\hline 1 & - & + \\
\hline 0.5 & - & + \\
\hline 0.25 & \pm & + \\
\hline 0.13 & + & + \\
\hline
\end{tabular}

a The degree of inhibition was expressed as follows: -, more than $90 \%$ of cells undivided;, $\pm 90 \sim$ $10 \%$ of cells divided; + , more than $90 \%$ of cells divided.

The cultured medium (2 liters)

Filtered through a paper filter.

The filtrate (2 liters)

Extracted with ethyl acetate.

The ethyl acetate fraction $(42 \mathrm{mg}$ )

Washed with acidified water $(\mathrm{pH} \mathrm{4.0)}$ and distilled water.

Plate chromatography on Kieselgel $\mathrm{HF}_{254}(20 \times 20 \mathrm{~cm})$

Developed with benzene-ethyl acetatemethanol $(50: 50: 1, \mathrm{v} / \mathrm{v})$.

The PC fraction at $R f 0.16(5 \mathrm{mg})$

Recrystallized with ethyl acetatemethanol.

Needles $(2 \mathrm{mg})$

FIG. 1. Procedure of Purifying Aphidicolin from Culture Filtrate of Harziella entomophila as an Inhibitor of Cleavage of Sea Urchin Embryos at the 1-Cell Stage. filtrate with ethyl acetate (Fig. 1). Table II shows that the ethyl acetate fraction at the concentration of $25 \mu \mathrm{g} / \mathrm{ml}$ inhibited mitotic division whereas starfish oocyte maturation proceeded normally in the presence of 4 times higher concentration of the fraction. The PC fraction responsible for the mitotic inhibition was obtained by plate chromatography (Fig. 1), The crystal obtained from the fraction carried the biological activity (Table II). Since the fungus has been shown to produce aphidicolin under similar culture conditions and the chromatographic behaviour is the same with that of aphidicolin as shown by three of the authors (K.K., Y.K. and A.S.), ${ }^{16 /}$ the crystal was directly compared with authentic aphidicolin. Their acetonides showed an identical retention time $(25 \mathrm{~min})$ on gas-liquid chromatographic analysis under the conditions described in MATERIALS AND METHODS. The crystal, authentic aphidicolin and their mixture showed the same melting point at $233^{\circ} \sim 236^{\circ} \mathrm{C}$. These results demonstrate clearly that the crystal is aphidicolin. The biological activity of authentic aphidicolin is the same with that of the crystal obtained in the present study (Table II).

Aphidicolin was originally obtained from the culture filtrate of the fungus Cephalosporium aphidicola and its structure was convincingly determined by Dalziel et al. ${ }^{5)}$ Bucknall et al. ${ }^{17}$ reported that aphidicolin inhibits the growth of herpes simplex virus cultured on human embryonic lung cells or on rabbit eyes. They also showed that aphidicolin inhibits the incorporation of thymidine into DNA of cultured human embryonic lung cells.

Effects of aphidicolin on cell divisions of other Echinoderm species than Clypeaster and Asterina

Clypeaster japonicus breeds during May, June and July at the coastal waters of Kanagawa. The breeding season of Asterina pectinifera there is May and June, and that at Mutsu Bay, Aomori, is August and September. Ripe ovaries can be obtained from the starfish collected at the vicinity of Uozu, Toyama, during 
November and December. Although breeding periods of these animals can be prolonged for more than 3 months in some case by keeping them in aquaria supplied with cold running sea water, it is desirable to test the effectiveness of the bioassay with other sea urchin species to be able to work at different periods of a year.

Aphidicolin at $40 \mu \mathrm{g} / \mathrm{ml}$ did not affect 1methyladenine $(45 \mathrm{ng} / \mathrm{ml})$-induced maturation in oocytes of Asterias amurensis. The breeding season of the starfish is January to April at the vicinity of Tokyo and May to July at Akkeshi, Hokkaido. The minimum effective concentrations of aphidicolin to block mitotic cell divisions of Anthocidaris crassispina and Hemicentrotus pulcherrimus embryos were nearly the same with those found in Clypeaster japonicus embryos (Table III). Anthocidaris crassispina spawns during July and August at Sagami Bay. Hemicentrotus pulcherrimus breeds during January to April at Sagami Bay and near Tamano, Okayama.

No species specificity of the aphidicolin action was observed in the present study.

TABle III. InHIBITORY EfFects of ApHIdicolin on Cell Division of Clypeaster japonicus, Hemicentrotus pulcherrimus AND Anthocidaris crassispina EMBRYOS AT THE 1-CELL STAGE ${ }^{a}$

\begin{tabular}{cccc}
\hline $\begin{array}{c}\text { Concentration of } \\
\text { aphidicolin } \\
(\mu \mathrm{g} / \mathrm{ml})\end{array}$ & $\begin{array}{c}\text { Clypeaster } \\
\text { japonicus }\end{array}$ & $\begin{array}{c}\text { Hemi- } \\
\text { centrotus } \\
\text { pulcherrimus crassispina }\end{array}$ & $\begin{array}{c}\text { Antho- } \\
\text { cidaris }\end{array}$ \\
\hline 1 & - & - & - \\
0.5 & - & \pm & \pm \\
0.25 & \pm & \pm & \pm \\
0.13 & + & + & + \\
\hline
\end{tabular}

a Degree of inhibition, see Table II.

\section{DISCUSSION}

Starfish oocytes are ideal cells for investigating meiotic maturational divisions since they can be obtained in great numbers, they are arrested at the dictyate stage of meiosis, and they divide rapidly and synchronously after 1-methyladenine addition. ${ }^{3)} \quad$ Meiotic maturation as induced by 1 -methyladenine is essentially a reduction in chromosome number. In other words, no chromosome replication takes place during maturational divisions. We have demonstrated in this study that inhibitors of DNA synthesis have no effects on the maturational process.

Sea urchin eggs are ideal cells for studies of the control of DNA synthesis because they can be obtained in great numbers, they incorporate radioactive precursors into DNA, they are very synchronous, and the period of synthesis is short and very definable in time. DNA synthesis is essential for the successful cleavage and development. The dependence of cleavage on the synthesis of DNA may need some words since the famous experiment by Harvey ${ }^{18}$, showed that parthenogenetically-activated annucleate halves of sea urchin eggs can cleave in an orderly manner. In later studies, ${ }^{13}$, however, she demonstrated that capabilities of the öoplasm to cleave were altered after fertilization, in that annucleate halves derived from fertilized eggs did not cleave while the nucleated halves developed normally. The synthesis of proteins necessary for cleavage depends upon the synthesis of DNA according to the observations by Young et al. ${ }^{17}$ with the sand dollar Echinarachnius parma embryos.

The bioassay system for the detection of inhibitors of DNA synthesis as proposed in this study depends on the assumption that test samples are permeable equally to sea urchin embryos and starfish oocytes. The premise is not unreasonable in the case of lipophilic and non-ionic chemicals, aphidicolin being one of them, since a barrier to passive movements of such chemicals across plasma membranes is quite small. ${ }^{20)}$

The experimental results described in this study suggest that aphidicolin is a selective inhibitor of DNA synthesis in sea urchin embryos. However, more detailed informations are obviously required to support this. In this context, one of the authors (S.I.) has recently obtained evidence supporting the procepure and verifying the usefulness of our procedure to detect inhibitors of DNA synthesis. The findings, which were reported in a brief preliminary form, ${ }^{21)}$ are as follows. The incorporation of thymidine into DNA of Hemicentrotus 
pulcherrimus embryos was inhibited by $90 \%$ with a $2 \mu \mathrm{g} / \mathrm{ml}$ concentration of aphidicolin which inhibited mitosis and cytokinesis of $90 \%$ of the embryos. A similar result was obtained with Clypeaster japonicus embryos (S.I., to be published). Aphidicolin at $10 \mu \mathrm{g} / \mathrm{ml}$ did not affect leucine incorporation into protein fraction of Hemicentrotus pulcerrimus embryos at the 1-cell stage. Aphidicolin did not affect uridine incorporation into RNA of sea urchin embryos at the gastrula stage. Aphidicolin at $2 \mu \mathrm{g} / \mathrm{ml}$ inhibited $90 \%$ of the activity of DNA polymerase $\alpha$ obtained from nuclei of Hemicentrotus pulcherrimus embryos without affecting the activity of DNA polymerases $\beta$ and $\gamma$. This suggests that aphidicolin blocks mitotic cell division by interfering with the activity of DNA polymerase $\alpha$ and that DNA polymerase $\alpha$ is the enzyme responsible for replication of DNA in sea urchin embryos. Further, aphidicolin has been shown to inhibit the activity of DNA polymerase $\alpha$ obtained from regenerating rat liver without affecting the activity of DNA polymerase $\beta$ and mitochondrial DNA polymerase. ${ }^{22}$ Aphidicolin had no effects on the activity of thymidine kinase obtained from rat liver. Activities of Escherichia coli DNA polymerase I and avian myeloblastosis virus reverse transcriptase remained unchanged by the treatment with aphidicolin. ${ }^{22)}$ The remarkable biological activity of aphidicolin shown by these studies will be the basis for using the drug as a tool of dissecting the specific step in chromosomal replication, thereby better understanding of the mechanisms governing the complex process of replication can be achieved.

Acknowledgement. We thank Professor Emeritus S. Tamura for encouragement and Dr. H. Nagano for helpful suggestions. Thanks are also due to Drs. B. Hesp and N. Otake for supplying some of the chemicals used in the present study, and staff members of Misaki Marine Biological Station, University of Tokyo, for supplying the starfishes and sea urchins.

\section{REFERENCES}

1) C. W. Young, F. J. Hendler and D. A. Karnofsky, Exp. Cell Res., 58, 15 (1969).

2) F. Zampetti-Bosseler, G. Huez and J. Brachet, ibid., 78, 383 (1973).

3) H. Kanatani, Am. Zool., 15, 493 (1973).

4) S. Ikegami, Y. Kamiya and H. Shirai, Exp. Cell Res., 103, 233 (1976).

5) W. Dalziel, B. Hesp, K. M. Stevenson and J. A. J. Jarvis, J. Chem. Soc. Perkin Trans. I., 1973, 841.

6) N. R. Cozzarelli, Ann. Rev. Biochem., 46, 641 (1977).

7) J. J. Furth and S. S. Cohen, Cancer Res., 28, 2061 (1968).

8) C. K. Mathews, Exp. Cell Res., 92, 47 (1975).

9) M. R. Siegel and H. D. Sisler, Biochim. Biophys. Acta, 87, 70 (1964).

10) N. Suzuki and Y. Mano, Develop. Growth Differ., 15, 113 (1973).

11) E. H. Davidson, "Gene Activity in Early Development," 2nd ed., Academic Press, New York, 1976.

12) E. Reich and I. H. Goldberg, Prog. Nucleic Acid Res. Mol. Biol., 3, 184 (1964).

13) P. R. Gross and G. H. Cousineau, Exp. Cell Res., 33, 368 (1964).

14) J. Bryan, Biochemistry, 11, 2611 (1972).

15) B. De Kruijff and R. A. Demel, Biochim. Biophys. Acta, 339, 57 (1974).

16) K. Kawada, Y. Kimura, K. Katagiri, A. Suzuki and S. Tamura, Agric. Biol. Chem., 42, 1611 (1978).

17) R. A. Bucknall, H. Moores, R. Simms and B. Hesp, Antimicrob. Agents Chemother., 4, 294 (1973).

18) E. B. Harvey, Biol. Bull., 71, 101 (1936).

19) E. B. Harvey, ibid., 78, 412 (1940).

20) A. C. Giese, "Cell Physiology," 4th ed., W. B. Saunders Co., Philadelphia, 1973, p. 265.

21) S. Ikegami, T. Taguchi, M. Ohashi, M. Oguro, H. Nagano and Y. Mano, Nature, 275, 458 (1978).

22) M. Ohashi, T. Taguchi and S. Ikegami, Biochem. Biophys. Res. Commun., 82, 1084 (1978). 